\title{
SOME SIMPLE $S-N$ RELATIONSHIPS IN FATIGUE OF TUBULAR K-JOINTS
}

\author{
by YOSHIAKI KUROBANE* and MITSUO KONOMI** \\ Members, A.I.J.
}

\section{Introduction}

Tubular $\mathrm{K}$-joints under a dynamic load sustain fatigue crack initiations at the points along the toes of brace to chord welds where the bending stress in the tube walls concentrates. The fatigue cracks extend first along the weld toes and then into the tube walls, until the joints become unstable. Number of cycles required for a crack initiation and a complete rupture varies with geometric parameters of the joints as well as the levels and type of cyclic loads. Efforts have been made to correlate these variables with the fatigue life of the joints, but the results have so far been unsatisfactory, because the response of the joints to an applied load is so complicated.

A look at fatigue test results, however, reveals the fact that the fatigue life (or fatigue strength) of the tubular $\mathrm{K}$-joint is generally greater for the joint with greater static strength than the others. The relationships between the fatigue and static strengths are fairly consistent for a variety of the tubular K-joints. It was found that, when the dimensions of the joint are within a range covered by the fatigue tests, the fatigue strength of a $\mathrm{K}$-joint can be estimated from the static strength with a reasonable accuracy.

In this report the fatigue strength of tubular $\mathrm{K}$-joints is expressed in terms of a ratio of the fatigue strength to the static strength, with which $S-N$ diagrams are established for all the joints tested by the authors. The results show that one $S-N$ curve is a good approximation to represent the fatigue behavior of various types of tubular $\mathrm{K}$-joints supporting the foregoing statement. Since the patterns of static and fatigue failures vary with the joint types, care must be taken of the limitations within which each $S-N$ curve is applicable. These limitations are discussed also in the following section. It is hoped that the $S-N$ diagrams proposed here will provide a better background for the proper design of $\mathrm{K}$-joints.

\section{Fatigue Strength}

The fatigue strength of the tubular $\mathrm{K}$-joint is defined in different ways with the investigators. An axial force in a brace, an average stress in a brace and an average stress in a shear area at the brace to chord welds have been used as a component of the stresses to show the fatigue strength. In the following sections the fatigue strength is being represented by the load range divided by the static strength of the joint.

The representation of the fatigue strength in this dimensionless form was used also in a previous paper $^{(1)}$ for two reasons :

1. Designers may easily obtain a general idea of the fatigue strength when it is expressed in terms of a ratio to the static strength.

2. Since local bending of the tube walls is the governing factor to both of the static and fatigue failures of the joint, with this form of representation it is possible to eliminate the effect of small variations in the dimensions of the joint and to decrease the scatter of the data on $S-N$

* Professor, Department of Architecture, Kumamoto University, D. Eng.

** Engineer, Nippon Kokan K.K. 
diagrams.

The second of the above two reasons was found to be reasonable because for most $\mathrm{K}$-joints the fatigue strength increased as the static strength increased. Further discussions on this problem are made in the following sections.

The load range $P_{r}$ is defined as the range of the load applied at the end of the "critical brace", and is equal to the difference between the maximum and minimum loads in the load cycle. As mentioned in the foregoing, fatigue cracks were usually found at the toes of the brace to chord welds. These cracks grew steadily until they eventually led to a complete separation of the brace from the chord. The critical brace being referred here is the brace in which such a failure occurred.

The static strength $P_{u}$ is defined as the maximum axial force in the same critical brace when the joint fails as a result of excessive bending deformations of the tube walls at the bottom of this brace or in the chord underneath this brace. There are various modes in the failure pattern of the tubular $\mathrm{K}$-joints. Tearing of a tension member and local buckling of a compression member are also examples of the failure modes. Regardless of the actual failure pattern of the joint under consideration, however, the static strength is assumed to be the ultimate strength of the joint when a failure is governed by local deformations of the tube walls at the portions where the critical brace is welded.

Such static strength may be estimated by the semi-empirical equation ${ }^{(2),(3)}$ developed at Osaka University for the joints of which static test results are not available. The equation is :

where

$$
\left.\begin{array}{l}
P_{u}=\sigma_{Y} T^{2} \sqrt{a / T f}(g / D)(1+6.52 d / D)\left(1-0.26 \cos ^{2} \theta\right)\left[1-0.23\left(n+n^{2}\right)\right] / \sin \theta \\
f(g / D)=1.75-2.65 g / D, \text { for } 0 \leq g / D \leq 0.23 \\
f(g / D)=1.15-0.06 \mathrm{~g} / D, \text { for } 0.23 \leq g / D \leq 1.8
\end{array}\right\}
$$

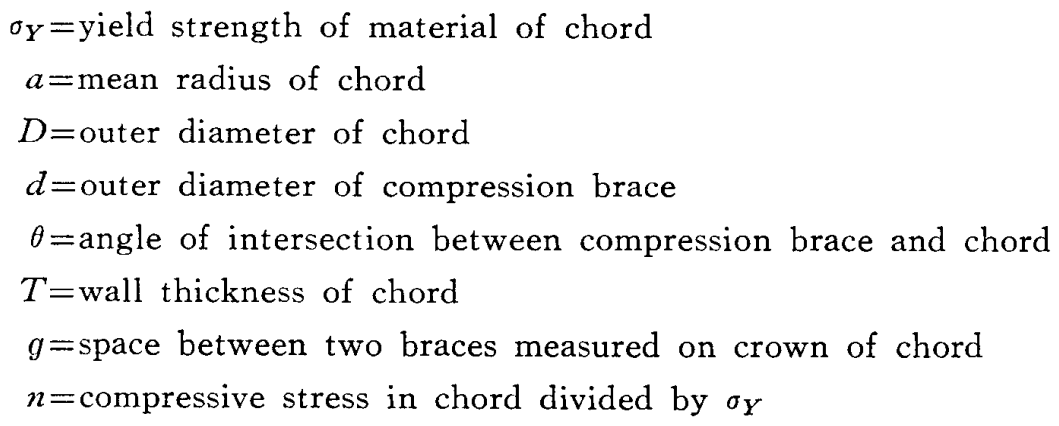

Attention must be paid to the fact that $P_{\boldsymbol{u}}$ in Eq. 1 is the ultimate axial force in the compression L brace when the $\mathrm{K}$-joint fails owing to local deformations of the tube walls at the points where the compression brace is welded. Even if the critical brace is under fluctuating tension, the static strength must be calculated assuming that the critical brace is under compression, because the static strength is used as a constant to account for the stiffness of tube walls to local deformation.

The fatigue strength of the tubular $\mathrm{K}$-joint $S$ is written in a following form :

$$
S=\left(P_{\max }-P_{\min }\right) / P_{u}=P_{r} / P_{u}
$$

Since $S$ is dimensionless, differences in size and mechanical properties of the materials are not taken into account to compare the $S-N$ relationships on diagrams in the following sections.

It is obvious from Eq. 2 that the only variable of " $S$ " is the load range. The other components of load cycle, such as the mean load, are not considered in the later discussions and simply treated as an unknown factor that causes the scatter of fatigue strength.

\section{$\boldsymbol{S}-\boldsymbol{N}$ Relationships of $\mathbf{K}$-Joints}

A series of fatigue tests has been performed on tubular $\mathrm{K}$-joints having a chord of $138.9 \mathrm{~mm}$ in outer diameter and two braces framing into it at an intersecting angle of $60^{\circ}$. The variables in joint dimensions were the wall thickness of the chord $T$ (of 4.0 and $4.5 \mathrm{~mm}$ ), the outer diameter of the

brace $d$ (of $60.5,76.3$ and $89.1 \mathrm{~mm}$ ) and the space between the two braces measured on the chord surface $g$ (of $30,25,11,-30$ and $-48 \mathrm{~mm}$ ). When the two braces overlapped, the space $g$ was 
assumed to be negative. All the spcimens were tested under completely reversed loads. Further details of the tests are described in the Appendix.

The $S-N$ relationships obtained in these tests are plotted in Figs. 1 and 2, where $N$ in Fig. 1 is the number of cycles to crack initiation and $N$ in Fig. 2 is the number of cycles to complete failure. Marks $O$ and

- in these figures indicate whether the specimens have extended braces $(g>0)$ or overlapping braces $(g<0)$, respectively. The results of the previous tests on low. cycle fatigue of $\mathrm{K}$-joints ${ }^{(1)}$ are also plotted in the same figures.

Initiating cracks were found when they were about $20 \mathrm{~mm}$ long. Since the detection of an initiating crack is the matter of skill, personal errors are unavoidable and the data in Fig. 1 scatter more than those in Fig. 2. The cycles to complete failure were the cycles when fatigue loading was not able to continue any longer. The fatigue cracks propagated very rapidly to deteriorate the carrying capacity at the final stage of fatigue testing. It is therefore expected that errors involved in the cycles to failure are less than 1 per cent.

It is observed in the log-log plots of the $S-N$ relationships that the data of the joints with extended braces generally fall

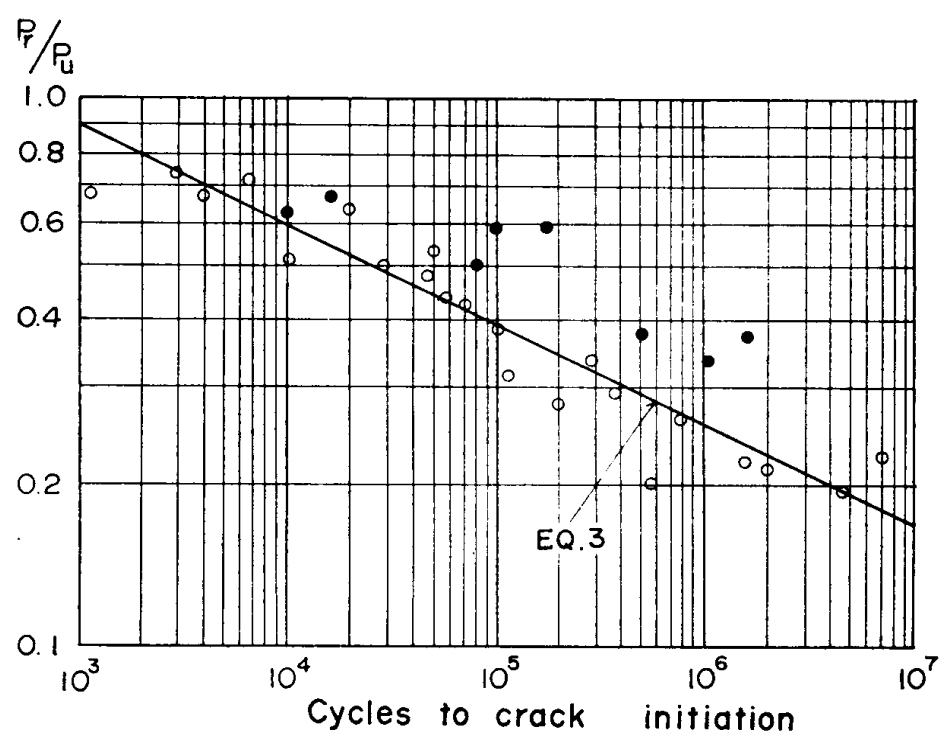

Fig. $1 S-N$ Relationships for K-Joints

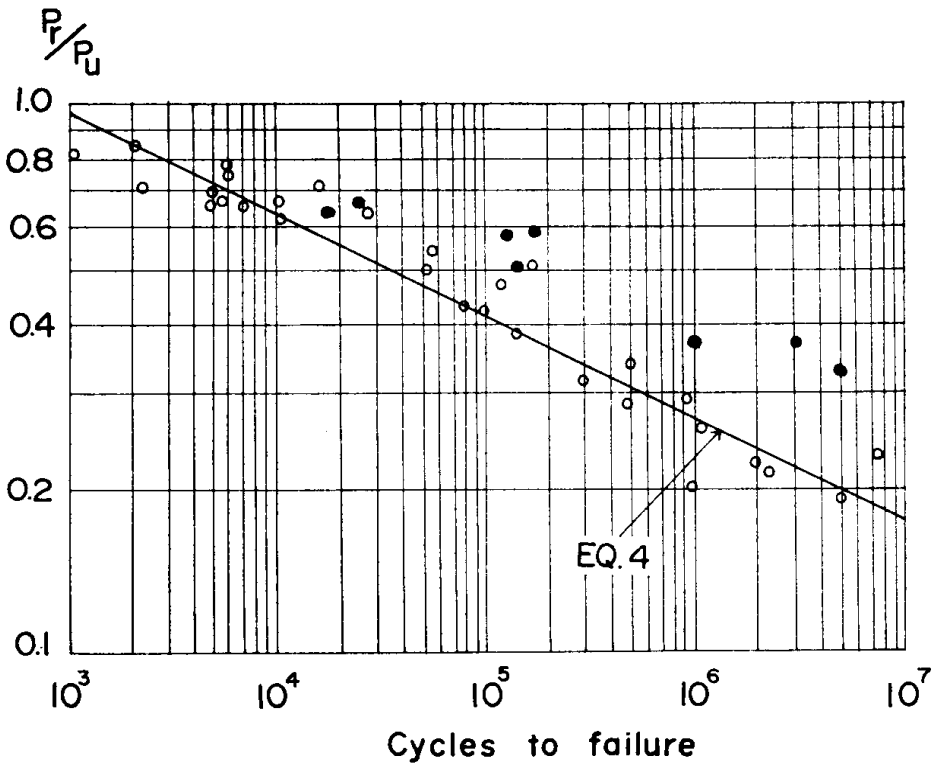

Fig. $2 S-N$ Relationships for K-Joints on a straight line in spite of the fact that $T, d$, and $g$ are varied. The best-fit curves were calculated by the method of least squares and are drawn in Figs. 1 and 2. These curves are : when $N=$ cycles to crack initiation,

$$
\log P_{r} / P_{u}=-0.1887 \log N+0.5264 \quad(s=0.06166)
$$

and when $N=$ cycles to complete failure,

$$
\log P_{r} / P_{u}=-0.1778 \log N+0.5094 \quad(s=0.06683)
$$

where $s$ is the sample standard deviation of $P_{r} / P_{u}$ about the fitted curve.

The data of the joints with overlapping braces deviate upwards from the best-fit curves, indicating that these joints are stronger than the others. The mechanical properties of the $\mathrm{K}$-joints with overlapping braces are complex and influenced by geometrical parameters that would be unimportant for the joints with extended braces. No formula has been found yet to predict the static strength of the joints of this type. For plotting the data of these joints on Figs. 1 and 2, the static strength was calculated simply assuming that $g=0$, even though $g<0$ because the braces overlapped. The test results indicate that the joints with overlapping braces have the greater fatigue strength than those with extended braces in terms of average stress in the brace, although no quantitative conclusion can be drawn from them.

A number of investigations have been reported so far on the elastic stresses in tubular $T, Y$ and 
K-joints. According to a parameter study on the stresses of these joints ${ }^{(4)}$, the peak stresses at the points of stress concentration can be approximated by the following mathematical models :

for T-joints,

$$
\sigma_{\max }=\frac{0.62 D^{0.7}}{T^{1.0} d^{1.1}} P
$$

and for $\mathrm{K}$-joints having extended braces,

$$
\sigma_{\max }=\sin ^{1.5} \theta \frac{0.35 D^{0.7}}{T^{1.6} d^{1.1}} P
$$

where $\sigma_{\max }$ is the peak stress and $P$ is the axial force in the brace.

The axial force in the brace when yielding commences at the point of stress concentration is obtained by equating $\sigma_{\max }$ to $\sigma_{Y}$. Thus, the initial yield load $P_{Y}$ is : in $T$-joints,

$$
P_{Y}=\frac{T^{1.6} d^{1.1}}{0.62 D^{0.7}} \sigma_{Y}
$$

and for $\mathrm{K}$-joints,

$$
P_{Y}=-\frac{1}{\sin ^{1.5} \theta} \frac{T^{1.6} d^{1.1}}{0.35 D^{0.7}} \sigma_{Y}
$$

It is readily be noticed that Eqs. 7 and 8 have similar forms to Eq. 1 and, therefore, that both the static strength and the initial yield load of $\mathrm{T}$ and $\mathrm{K}$-joints vary with $T, d, D$ and $\theta$ in a similar manner. Note that Eq. 1 gives the static strength of the K-joint with extended braces and, if $g / D$ is taken as 1.8, gives the static strength of the $\mathrm{T}$ and $\mathrm{Y}$-joints.

According to the test results, the fatigue strength was only a function of the number of cycles applied. Varying such dimensions as $T, d$ and $g$ gave no important effects on the fatigue strength. This may be intuitively reasonable, because, as the static strength increases, the maximum stress at the points of stress concentration decreases, which would result in an increased resistance to fatigue loads. If both the fatigue and static resistances increase at the same rate when $T$ and $d$ are increased and $g$ is decreased, the fatigue strength as defined here must be insensitive to the variation in $T$, $d$ and $g$. This was the case in the tubular $\mathrm{K}$-joints with extended braces as the test results indicated. The increase in $T$ and $d$ and the decrease in $g$ may have the effects to stiffen the tube walls against failure due to local bending and to improve equally the resistances of the joint to both the static and fatigue loads.

The $S-N$ relationships herein discussed were basing on the test results in which the dimensions of the specimens were varied within a limited range. The important limitations above all are :

1. All the specimens are of small size. The chords are of $139.8 \mathrm{~mm}$ and $101.6 \mathrm{~mm}$ in O.D..

2. $D / T$-ratio varies between 32 and 41 .

3. The braces frame into the chord at $60^{\circ}$ for all of the specimens.

To check the $S-N$ relationships of the $\mathrm{K}$-joints of different types as far as possible, the $S-N$ curve was compared with the results of tests performed at the University of California ${ }^{\left.(5),{ }^{6}\right)}$, Ishikawajima Harima Heavy Industries, Co., Ltd. (7), The University of Texas ${ }^{(8)}$, Nippon Kokan K.K. ${ }^{(9)}$ and Mitsui Shipbuilding \& Engineering Co. ${ }^{(10)}$. The details of the specimens in these tests are shown in Table 1.

\begin{tabular}{|c|c|c|c|c|c|}
\hline \multicolumn{2}{|c|}{ Chord } & \multirow{2}{*}{$\begin{array}{l}\text { Brace } \\
\begin{array}{l}\text { Outer } \\
\text { diameter, } \\
\text { in mm }\end{array}\end{array}$} & \multirow{2}{*}{$\begin{array}{l}\text { Angle of } \\
\text { intersection } \\
\text { between chord } \\
\text { and braces }\end{array}$} & \multirow[b]{2}{*}{$\begin{array}{c}g \\
\text { in } \mathrm{mm}\end{array}$} & \multirow[b]{2}{*}{$\begin{array}{l}\text { Reference } \\
\text { number }\end{array}$} \\
\hline $\begin{array}{l}\text { Outer } \\
\text { diameter, } \\
\text { in } \mathrm{mm}\end{array}$ & $\begin{array}{l}\text { Wall } \\
\text { thickness, } \\
\text { in } \mathrm{mm}\end{array}$ & & & & \\
\hline $\begin{array}{l}323.9 \\
323.9\end{array}$ & $\begin{array}{r}8.4 \\
14.3\end{array}$ & $\begin{array}{l}141.3 \\
141.3\end{array}$ & $35^{\circ} \sim 90^{\circ}$ & 37.3 & 5,6 \\
\hline $\begin{array}{l}165.2 \\
165.2 \\
165.2\end{array}$ & $\begin{array}{l}4.5 \\
6.0 \\
7.1\end{array}$ & $\begin{array}{l}76.3 \\
76.3 \\
76.3\end{array}$ & $45^{\circ} \sim 45^{\circ}$ & 57.3 & 7 \\
\hline $\begin{array}{l}219.1 \\
219.1 \\
219.1\end{array}$ & $\begin{array}{l}4.8 \\
4.8 \\
4.8 \\
\end{array}$ & $\begin{array}{l}88.9 \\
88.9 \\
95.3\end{array}$ & $45^{\circ} \sim 90^{\circ}$ & $\begin{array}{r}53.0 \\
0.0 \\
45.4\end{array}$ & 8 \\
\hline $\begin{array}{l}267.4 \\
267.4 \\
267.4 \\
267.4\end{array}$ & $\begin{array}{l}9.3 \\
6.0 \\
5.0 \\
4.0\end{array}$ & $\begin{array}{l}101.6 \\
101.6 \\
101.6 \\
101.6\end{array}$ & $45^{\circ} \sim 90^{\circ}$ & 11.1 & 9 \\
\hline 457.2 & 4.5 & 165.2 & $45^{\circ} \sim 90^{\circ}$ & 29.2 & 10 \\
\hline
\end{tabular}
The test results are illustrated in Fig. 3, which plots the fatigue strengths of the

Table 1 Dimensions of $\mathrm{K}$-Joints Tested by Other Investigators

Nominal dimensions are given. 
$\mathrm{K}$-joints that have extended braces only.

It is observed in Fig. 3 that these fatigue data also gather around the $S-N$ curve obtained from the authers' test results (Eq. 4). The best-fit curve was calculated for all the test results of the $\mathrm{K}$-joints with extended braces, viz., for all of the thirtyone data in Fig. 2 and thirtyeight data in Fig. 3. The curve is shown by a solid line in Fig. 3 and can be written as :

$\log P_{r} / P_{u}=-0.1823 \log N$

$$
+0.5061(s=0.1143) \quad(9)
$$

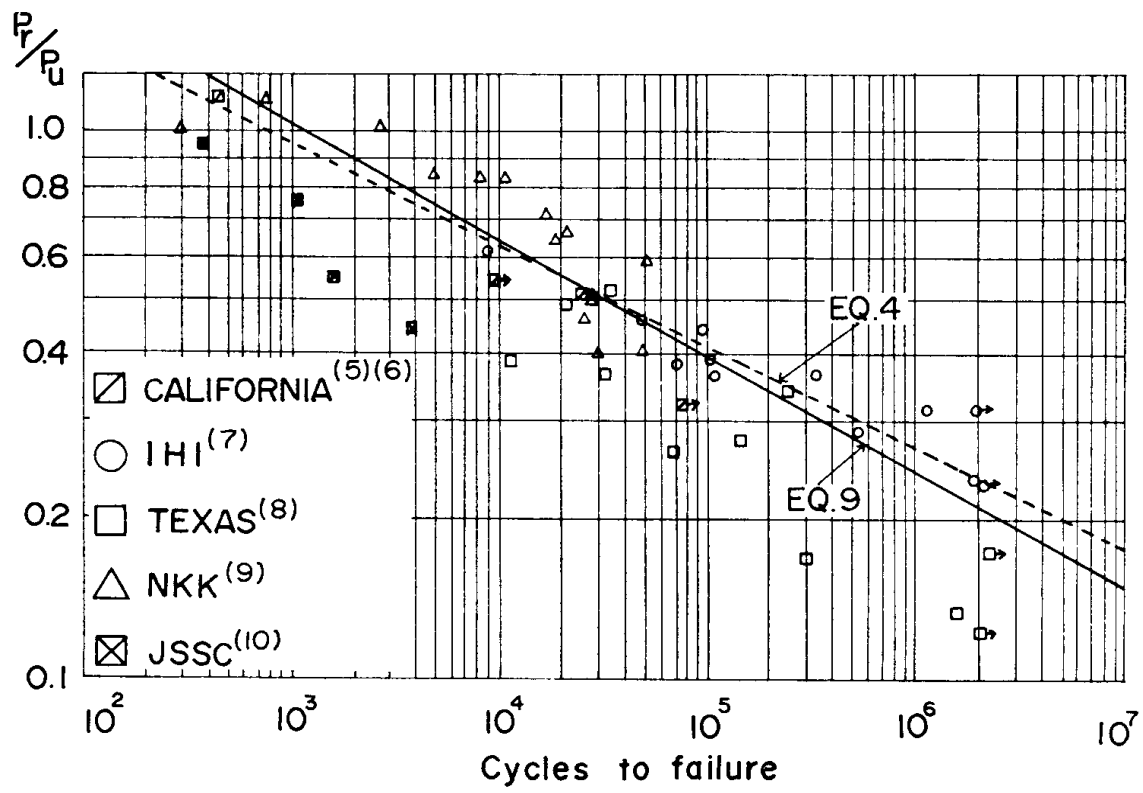

Fig. $3 S-N$ Relationships for K-Joints

which is very close to Eq. 4. The plotted points in Fig. 3 are dispersed more widely than those in Fig. 2. Nevertheless, it is worth noting that the one $S-N$ curve can roughly represent the fatigue strength of the tubular K-joints of various types, which were tested at the six different laboratories.

As a result of tests on small-sized specimens, Bader suggested allowable stress curves for fatigue design of tubular K-joints specified for various values of the "dimension constant" $\alpha_{D}{ }^{(11)}$. $\alpha_{D}$ was given by an empirical formula,

$$
\alpha_{D}=k \frac{d}{D} T
$$

where $k$ is a shape factor and can be assumed to be 1.0 for the joints with extended braces if their axes meet with the chord axis at one point. The allowable average stresses in the brace for the joint under reversal load were specified as follows ${ }^{(12),(13)}$.

\begin{tabular}{ccc}
$\alpha_{D}$ & \multicolumn{2}{c}{ allowable stress $\left(\mathrm{kg} / \mathrm{cm}^{2}\right)$} \\
& for $2 \times 10^{6}$ cycles & for $5 \times 10^{5}$ cycles \\
$\alpha_{D} \geq 2.0$ & 318 & 413 \\
$2.0>\alpha_{D} \geq 1.6$ & 227 & 318 \\
$1.6>\alpha_{D} \geq 1.2$ & 182 & 227
\end{tabular}

These allowable stresses were to be multiplied by $\sin \beta / \sin \theta$, where $\beta$ was the angle of intersection between the brace and the chord of his specimens.

It is therefore seen that, in the same way as the case of the static strength, the allowable stress for fatigue of the $\mathrm{K}$-joint increases with $d / D, T$ and $1 / \sin \theta$. In Fig. 4, the allowable fatigue strength obtained by the Bader's design formula is compared with the fatigue strength (in terms of axial force in the brace) derived from Eq. 4. The $\mathrm{K}$-joint selected for this comparison are of the type shown in Fig. 4 and identical to one of the typical specimens in the fatigue tests by Bader, et al. Although the Bader's design formula was basing on a limited

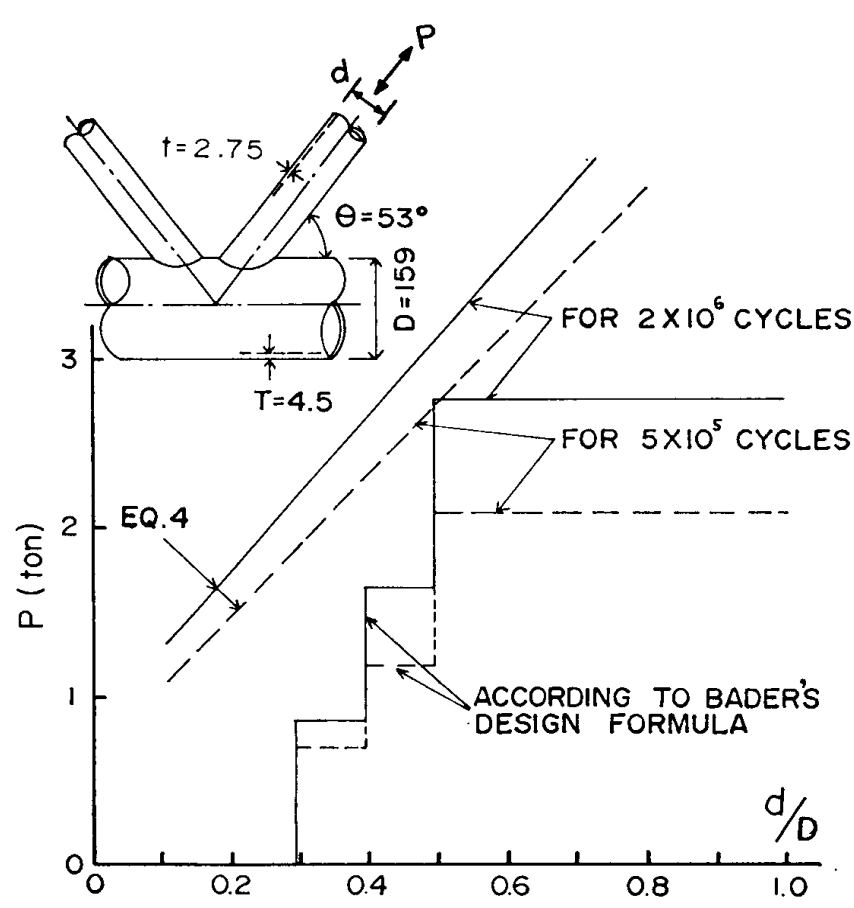

Fig. 4 Proposed Fatigue Strength Compared with Bader's Design Formula 
number of tests, it is seen in Fig. 4 that the formula agrees reasonably well with the fatigue strength proposed here if the dimensions of the joints are within a range covered by his tests.

\section{$\boldsymbol{S}-\boldsymbol{N}$ Relationships of Tubular $\mathbf{T}$ and Cross Joints}

It is interesting to compare the $S-N$ relationships of the $\mathrm{K}$-joints with those of tubular $\mathrm{T}$ and cross joints. The fatigue strength is expressed in the same dimensionless form as the foregoing.

The static strength of $\mathrm{T}$-joints can be calculated by a semi-empirical equations ${ }^{(14)}$,

$$
\left.\begin{array}{l}
P_{u}=0.2533 \sqrt{\frac{a}{T}}\left(80 \frac{\alpha}{\pi}+2\right) \sigma_{Y} T^{2} \\
\alpha=\sin ^{-1}(d / D)
\end{array}\right\}
$$

Eqs. 11 are essentially the same as Eq. 1 when $g / D$ was taken as 1.8 .

The static strength of cross joints can be given by a semi-empirical equation,

$$
P_{u}=6.19 \frac{1}{1-0.833 d / D} \sigma^{\sigma} T^{2}
$$

Both Eqs. 11 and 12 give the static carrying capacities of the joints in which the braces are under compression and failure occurs as a results of excessive bending deformations of the chord walls in the local areas under the braces.

Fatigue tests of $\mathrm{T}$-joints ${ }^{(8),(10),(15)}$ are plotted in Fig. 5. There are two different types in these $\mathrm{T}$-joint tests. One of them used the specimens of very small size (The chord had the outer diameter of $57 \mathrm{~mm}$ and the wall thickness of $1.2 \mathrm{~mm}$ ). Eightyseven data were obtained from the small-sized specimens. The other is the tests on larger sized specimens. $D$ was varied from $165.2 \mathrm{~mm}$ to $457.2 \mathrm{~mm}, D / T$ from 27 to 101 and $d / D$ from 0.22 to 0.89 . Thirty-five fatigue data were obtained from the tests on larger $\mathrm{T}$-joints.

The fatigue strength of the small-si-

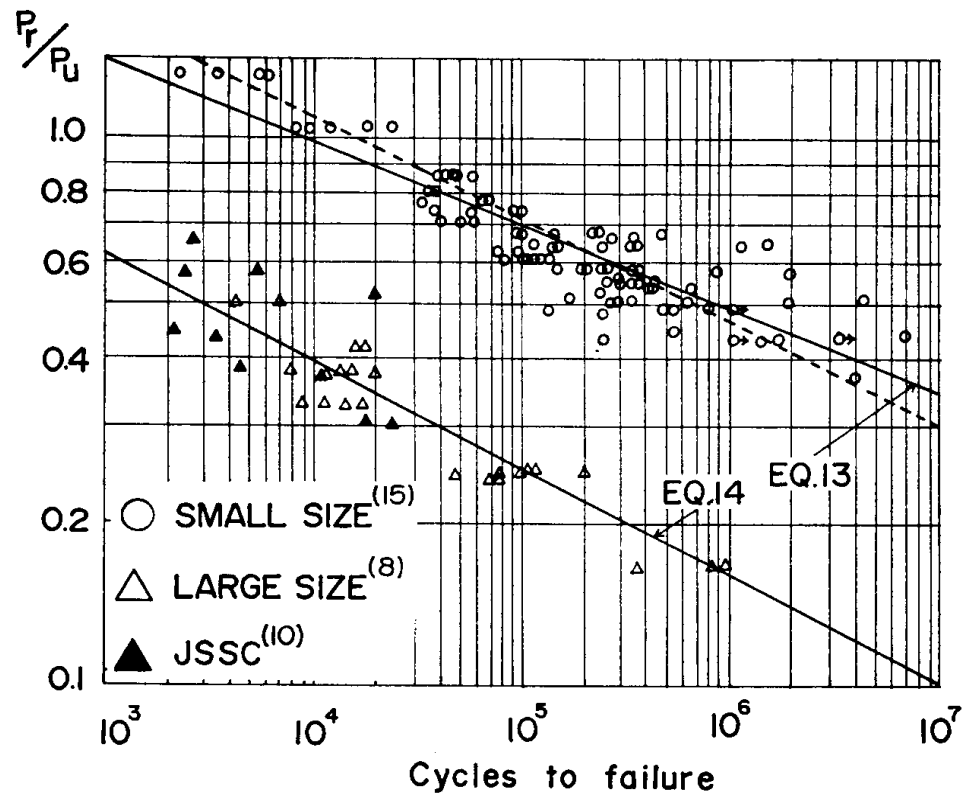

Fig. $5 S-N$ Relationships for T-Joints zed specimens was greater than that of the large-sized specimens as a result of size-effects and differences in welding conditions. Since the difference in fatigue behavior between the large and small specimens cannot be ignored, the best-fit curves were calculated independently for each of these two groups of data. These curves are :

for small-sized specimens,

and for large-sized specimens,

$$
\log P_{r} / P_{u}=-0.1528 \log N+0.6038 \quad(s=0.08855)
$$

$$
\log P_{r} / P_{u}=-0.1976 \log N+0.3827 \quad(s=0.06347)
$$

As seen in Fig. 5, the plotted points of each group gather around each of the best-fit curves irrespective of the fact that $T$ and $d / D$ are varied in these tests. The slope of the best-fit curve for the large-sized specimens is very close to that for the $\mathrm{K}$-joints. The slope of the best-fit curve for the small-sized specimens is slightly less than that for the $\mathrm{K}$-joints. Because most data concentrate between the fatigue lives of $10^{5}$ and $10^{6}$ cycles in the tests on the small-sized specimens, errors do not increase appreciably even if the best-fit curve is assumed to have the same slope as that for the $\mathrm{K}$ joints as shown by a dashed line in Fig. 5 .

The fatigue test results on tubular cross joints ${ }^{(10),(16)}$, are illustrated in Fig. 6. There were eighty-four data on the cross joints in which $D$ was varied from 76.3 to $318.5 \mathrm{~mm}, D / T$ from 18 to 71 and $d / D$ from 0.52 to 1 . The best-fit curve for them is : 
$\log P_{r} / P_{u}=-0.2107 \log N+0.6524$

$$
(s=0.1145)
$$

Although this curve has a little greater slope than that for the K-joints, the fatigue strength itself is of the same magnitude as that of the $\mathrm{K}$-joints.

It may be seen in these comparisons that the fatigue strength of the $T$ and cross joints is also insensitive to variations in $T$ and $d$ as in the case of the $\mathrm{K}$-joints.

\section{Summary and Conclusions}

(1) The fatigue strength was expressed by a dimensionless value, "(load range)/(static strength)',. From the $S_{-}$

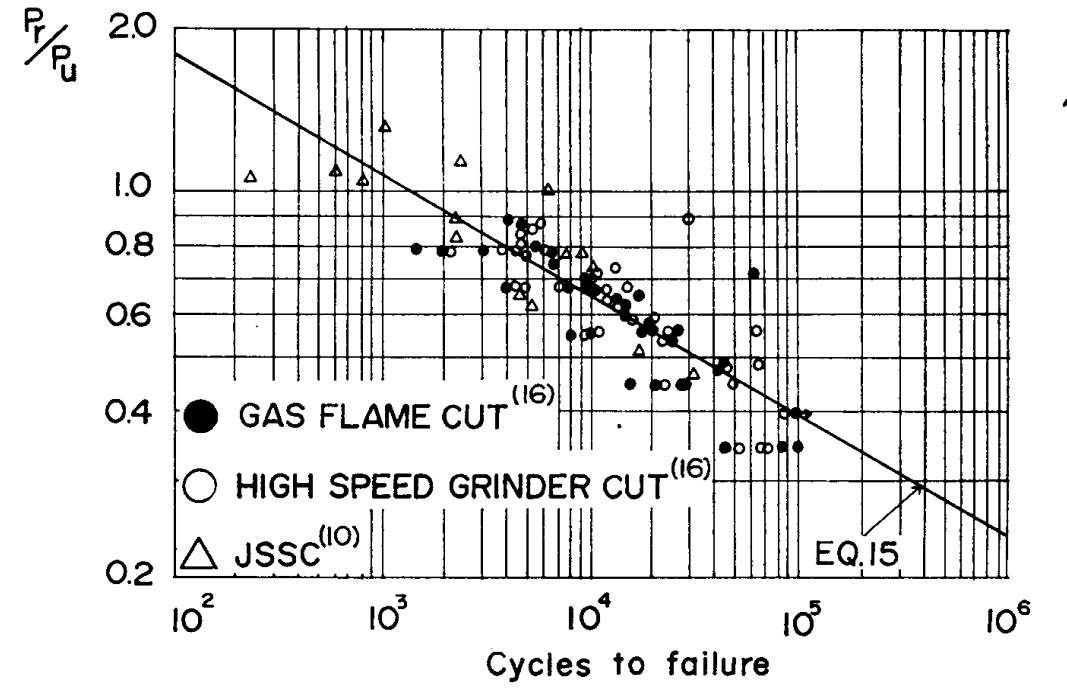

Fig. $6 S-N$ Relationship for Cross Joints

$N$ diagram(Fig. 2) that summarized the test results, such fatigue strengths of $\mathrm{K}$-joints were thought to follow a straight line rather closely for those with extended braces. The bestfit curve for it was written as :

$$
\log P_{r} / P_{u}=-0.18 \log N+0.51
$$

(2) Since the tests include six different types of K-joints, it may be hypothesized that the above $S-N$ curve represents the fatigue strength of the $\mathrm{K}$-joint irrespectively of dimensions and configuration of the joint.

(3) This hypothesis based upon limited test data. The fatigue tests were performed on the specimens with the chord of $139.8 \mathrm{~mm}$ and $101.6 \mathrm{~mm}$ in O.D. and of $D / T$-ratio ranging between 32 and 41 and with the two braces framing into the chord at $60^{\circ}$, but covered a life range of $10^{3}$ to $5 \times 10^{6}$ cycles. However, the $S-N$ relationships were compared with the results of tests carried out by the other investigators. In the latter tests, $D$ ranged between 165 and $457.2 \mathrm{~mm}, D / T$ ranged between 23 and 101 and angle of intersention between the chord and the brace varied between $35^{\circ}$ and $90^{\circ}$. It was found that these test results still supported the above hypothesis, although they showed a greater dispersion.

(4) It was also found that the tubular $T$ and cross joints had similar characteristics to tho $\mathrm{K}-$ joint in regard to the fact that fatigue strength was not affected by varying $D / T$ and $d / D$-ratios. This may suggest that, for the tube to tube joints in general, the static strength is an excellent measure to evaluate the capacities of the joints under fatigue loads.

(5) It is still difficult at the present stage to estimate the stress and strain conditions at the points where fatigue cracks initiate and grow and to correlate them to the fatigue strength of the joint. The $S-N$ curve proposed here may be utilized for the present as a simple and versatile criterion to predict the fatigue behavior of the $\mathrm{K}$-joint.

Attention must be paid to the fact that the number of the available test results were insufficient to preparation of a sound statistical evaluation of the data ${ }^{(17)}$. Engineering judgements must be exercised by the designers in order to apply the $S-N$ curve to the design of tubular $\mathrm{K}$-joints. Furthermore, care must be taken of the range of the tests upon which this $S-N$ curve based. Additional fatigue tests are most recommended to design a joint having the dimensions that are very different from those of the specimens in this report.

(6) The K-joints with overlapping braces have the greater fatigue strength than the others. Although the behavior of these joints are still unknown in many respects, they have obviously excellent mechanical properties under both static and fatigue loads. It may be advantageous to carry these 
joints into design practice.

\section{Acknowledgement}

The writers wish to thank the Kawasaki Heavy Industreis, Ltd. for grants in support of this investigation.

\section{References}

1) Y. Kurobane, Y. Makino and M. Sagawa, "Low-Cycle Fatigue Research on Tubular K-Joints", Memoirs, Faculty of Engrg., Kumamoto Univ., Vol. XVI, No. 2, also IIW Doc. XV-291-70 (May 1970)

2) K. Washio, T. Togo and Y. Mitsui, "Experimental Study on Local Failure of Chords in Tubular Truss Joints (I )", Technology Reports, Osaka Univ. Vol. 18, No. 850 (1968)

3) K. Washio, T. Togo and Y. Mitsui, "Experimental Study on Local Failure of Chords in Tubular Truss Joints (II)," Technology Reports, Osaka Univ., Vol. 19, No. 874 (1969)

4) J.B. Reber, Jr., "Ultimate Strength Design of Tubular Joints", OTC 1664 (1972)

5) J.G. Bouwkamp, "Tubular Joints under Alternating Loads", Proc. 3rd Conf. on Dimensioning, Budapest (1968)

6) J.G. Bouwkamp, "Tubular Joints under Slow-Cycle Alternating Loads", Proc. Int. Symp. on the Effects of Repeated Loading on Materials and Structures, Rilem, Mexico City, Vol. VI (Sept. 1966)

7) T. Maeda, K. Uchio and H. Sakurai, "Experimental Study on the Fatigue Strength of Welded Tubular KJoints", IIW Doc. XV-269-69 (July 1969)

8) A.A. Toprac and B.G. Louis, "Research on the Fatigue Behavior of Tubular Connections", IIW Doc. XV-29370 (May 1970)

9) K. Kurokawa, T. Nakajima, M. Shimizu and T. Koshikawa, "Research on Fatigue Strength of Thin Walled Welded Tubular Joints-Part 1 Fatigue Tests, Part 2 Stress Analysis and Phote-Elastic Measurements”, Summary of Technical Papers of Annual Meeting of AIJ, (1972) in Japanese

10) “Test on Joints of Underwater Structures Part 1", Honshu-Shikoku Interconnection Bridge Agency, Unpublished Report Submitted by the Society of Steel Construction of Japan (March 1972) in Japanese

11) W. Bader, "Geschweisste Rohrausschlusse und Abkant-Hohlprofile bei Dynamische Beanspruchung", Schweisstechnik, $13 \mathrm{~J}$. (1963)

12) DDR-Standard, TGL 13500 (May 1965)

13) DDR-Standard, TGL 13501 (Sept. 1964)

14) H. Kanatani, "Experimental Study of Welded Tubular Connection (Part 2)", Trans. AIJ, No. 109 (March 1965) in Japanese

15) Y. Kurobane, M. Natarajan and A.A. Toprac, "Fatigue Tests of Tubular T-Joints", Structures Fatigue Research Lab., Univ. of Texas (Nov. 1967)

16) K. Washio, Y. Mitsui, Y. Nishida, T. Tanaka, N. Hisamitsu and S. Hozumi, "Study of Flat Cutting Method for End Preparation of Tube in Fabrication of Tubular Structures", Trans. AIJ, No. 154 (Dec. 1968) in Japanese

17) ASTM-Committee E-9, "A Guide for Fatigue Testing and Statistical Analysis of Fatigue Data”, STP-91 A (1963)

\section{APPENDIX Description of Tests}

The specimen configuration and dimensions are shown in Fig. A 1 and Table A 1. All of the tubes are of JIS STK 41 steel (roughly equivalent to ASTM A 36 steel). The mechanical properties of these materials were determined by tension testing of No. 12 standard coupons (gage length $=50$ $\mathrm{mm}$ ) specified in JIS $Z$ 2201. The coupons were cut from all the tested specimens for the chords and from tube stock for the braces. The mechanical properties thus measured are shown in Table A 2.

A completely reversed load was applied by a servo-valve controlled fatigue machine with the speed of 180 to $1500 \mathrm{cpm}$.. Loading devices were used so that the axial forces were applied to each end of the two braces and the chord. One end of the chord was free from any force. The test setup is depicted in Fig. A 2.

Fatigue cracks were observed on the surfaces of the as-welded specimens through a magnifying glass. Liquid penetrant was sprayed on the surfaces of the specimens. The penetrant bubbled out from the cracks under the action of pulsating loads, which facilitated the detection of the cracks. The chord was filled with surfactant solution. Leakage of the solution demonstrated a formation of a crack that penetrated through the chord wall.

The test results are summarized in Table A 3. The joints with extended braces developed the first crack at the toes of the brace to chord welds, on the crown where the two welds between the braces and the chord approached. The cracks extended first along the weld toes and then also into the chord wall. Fig. A 3 is an example of diagrams that illustrate the locations of the cracks. Fig. 
A 4 shows the failure mode of the specimens at the time when fatigue testing was terminated.

In the joints with overlapping braces, the first crack usually appeared at the points where the three welds met as shown in Fig. A 5. The cracks initiated at these points grew following complex paths : a branch of the cracks extended along the weld toes and occasionally grew across the welds;

Table A 1 Dimensions of Specimens

\begin{tabular}{|c|c|c|c|c|c|}
\hline \multirow{2}{*}{$\begin{array}{l}\text { Specimen } \\
\text { designation }\end{array}$} & \multicolumn{2}{|c|}{ Chord } & \multicolumn{3}{|c|}{ Brace } \\
\hline & $\begin{array}{l}\text { Outer diameter, } \\
\text { in } \mathrm{mm}\end{array}$ & $\begin{array}{l}\text { Wall thickness, } \\
\text { in } \mathrm{mm}\end{array}$ & $\begin{array}{l}\text { Outer diameter, } \\
\text { in mm }\end{array}$ & $\begin{array}{l}\text { Wall thickness*, } \\
\text { in mm }\end{array}$ & in $\begin{array}{c}g^{*} \\
\mathrm{~mm}\end{array}$ \\
\hline $\begin{array}{r}\mathrm{K} \text { 0-1 } \\
2 \\
3 \\
4 \\
5\end{array}$ & $\begin{array}{l}140.5 \\
140.8 \\
140.3 \\
139.9 \\
140.0\end{array}$ & $\begin{array}{l}3.93 \\
3.90 \\
3.91 \\
4.26 \\
4.20\end{array}$ & $\begin{array}{l}60.9 \\
60.7 \\
60.9 \\
61.0 \\
60.9\end{array}$ & $\begin{array}{c}3.2 \\
" \\
"\end{array}$ & $\begin{array}{l}30 \\
\prime \prime \\
25 \\
25\end{array}$ \\
\hline $\begin{array}{r}\text { KD76-1 } \\
2 \\
3 \\
4\end{array}$ & $\begin{array}{l}140.8 \\
140.8 \\
140.7 \\
139.9\end{array}$ & $\begin{array}{l}3.89 \\
3.89 \\
3.94 \\
4.37\end{array}$ & $\begin{array}{l}76.2 \\
76.5 \\
76.3 \\
76.5\end{array}$ & " & $\begin{array}{l}30 \\
\text { " } \\
25\end{array}$ \\
\hline $\begin{array}{r}\text { KD89-1 } \\
2 \\
3 \\
4 \\
\end{array}$ & $\begin{array}{l}140.0 \\
140.3 \\
140.4 \\
139.8\end{array}$ & $\begin{array}{l}3.95 \\
3.92 \\
3.92 \\
4.36 \\
\end{array}$ & $\begin{array}{l}89.8 \\
89.5 \\
89.6 \\
89.4\end{array}$ & " & $\begin{array}{l}30 \\
" 1 \\
25\end{array}$ \\
\hline $\begin{array}{r}\mathrm{KG} 10-1 \\
2 \\
3 \\
4\end{array}$ & $\begin{array}{l}140.4 \\
140.7 \\
140.4 \\
139.9\end{array}$ & $\begin{array}{l}3.97 \\
3.94 \\
3.91 \\
4.26\end{array}$ & $\begin{array}{l}60.9 \\
60.8 \\
60.6 \\
60.8\end{array}$ & " & 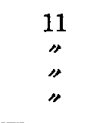 \\
\hline $\begin{array}{r}\text { K GMS-1 } \\
2 \\
3 \\
4\end{array}$ & $\begin{array}{l}140.3 \\
140.5 \\
140.6 \\
140.0\end{array}$ & $\begin{array}{l}3.94 \\
3.94 \\
3.92 \\
4.26\end{array}$ & $\begin{array}{l}60.8 \\
60.9 \\
61.0 \\
60.8 \\
\end{array}$ & ", & $\begin{array}{c}-30 \\
" \\
"\end{array}$ \\
\hline $\begin{array}{r}\text { K GMS 76-1 } \\
2 \\
3 \\
4 \\
\end{array}$ & $\begin{array}{l}140.0 \\
140.0 \\
140.1 \\
140.0 \\
\end{array}$ & $\begin{array}{l}4.38 \\
4.25 \\
4.21 \\
4.23\end{array}$ & $\begin{array}{l}76.5 \\
76.6 \\
76.8 \\
76.5 \\
\end{array}$ & " & $\begin{array}{c}-48 \\
" \\
"\end{array}$ \\
\hline $\begin{array}{r}\mathrm{KT} 45-1 \\
2 \\
3\end{array}$ & $\begin{array}{l}139.8 \\
139.8 \\
139.8\end{array}$ & $\begin{array}{l}4.42 \\
4.42 \\
4.42\end{array}$ & $\begin{array}{l}60.8 \\
60.9 \\
60.6\end{array}$ & " & $\begin{array}{l}30 \\
"\end{array}$ \\
\hline
\end{tabular}

* Nominal dimensions are given.

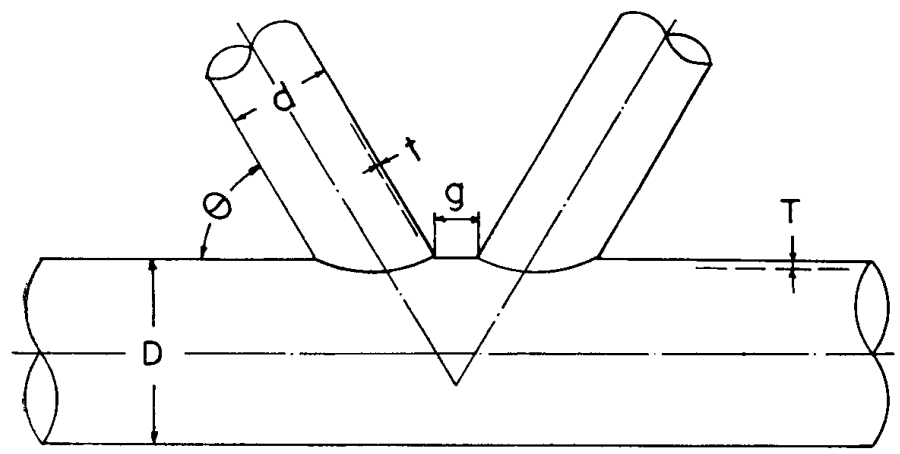

(a) K-joints with extended braces

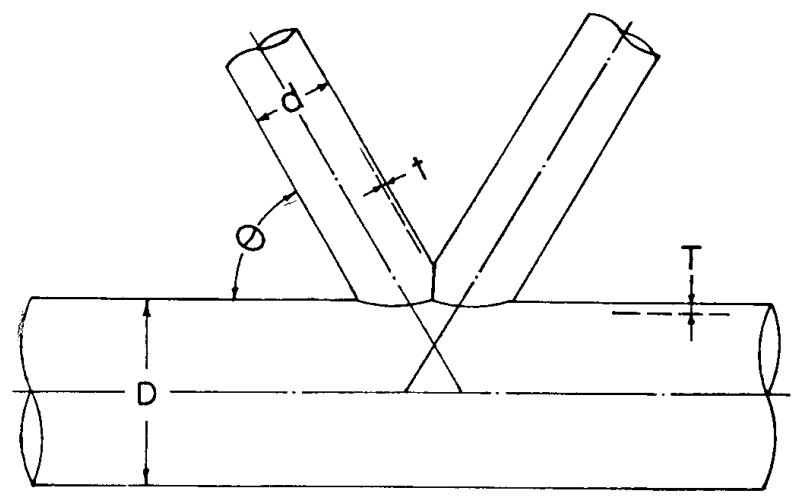

(b) K-joints with overlapping braces

Fig. A 1 Configuration of Typical Specimens

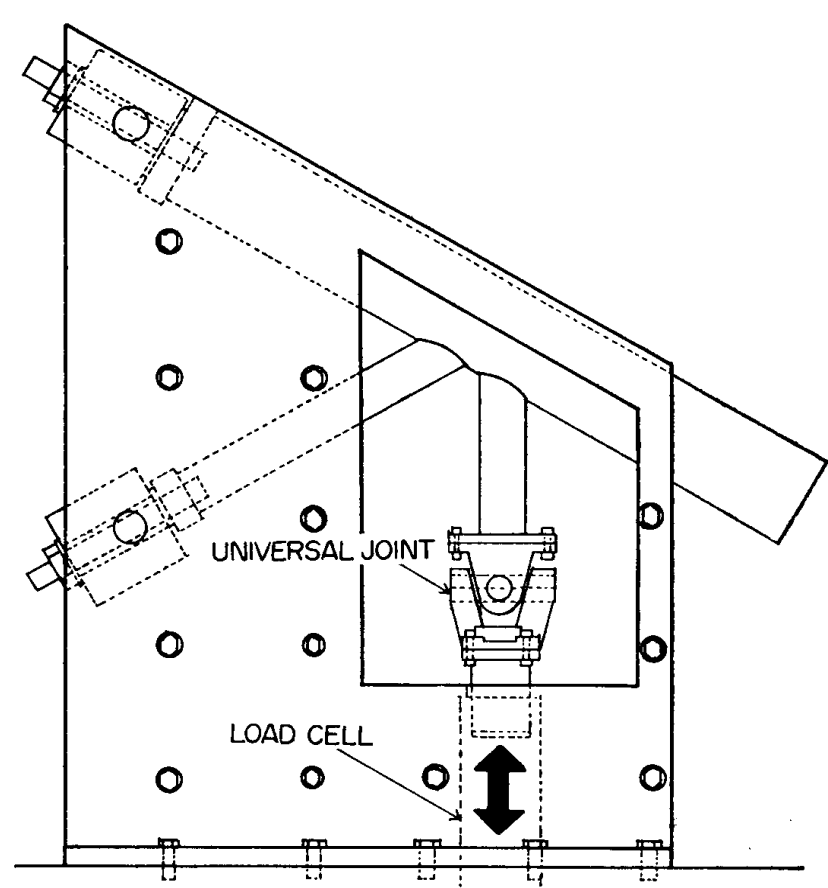

Fig. A 2 Test Set-Up 
another branch extended into the brace walls. Final failures were mostly governed by a separation of a brace from the joint as seen in Fig. A 6 .

The crack length is plotted against the number of cycles in Fig. A 7 for some of the specimens.

Table A 2 Mechanical Properties of Materials

\begin{tabular}{|c|c|c|c|}
\hline \multirow{3}{*}{$\begin{array}{l}\text { Specimen } \\
\text { designation }\end{array}$} & \multicolumn{3}{|c|}{ Mechanical properties of chords } \\
\hline & Tensile strength & Yield point & \multirow{2}{*}{$\begin{array}{l}\text { Elongation } \\
\text { in } \%\end{array}$} \\
\hline & \multicolumn{2}{|c|}{ in $\operatorname{ton} / \mathrm{cm}^{2}$} & \\
\hline $\begin{array}{r}\mathrm{K} 0-1 \\
2 \\
3 \\
4 \\
5\end{array}$ & $\begin{array}{l}4.93 \\
4.90 \\
4.93 \\
4.04 \\
4.04\end{array}$ & $\begin{array}{r}3.64 \\
3.64 \\
3.64 \\
3.42 \\
3.42\end{array}$ & $\begin{array}{l}33 \\
33 \\
33 \\
38 \\
38\end{array}$ \\
\hline $\begin{array}{r}\text { KD } 76-1 \\
2 \\
3 \\
4\end{array}$ & $\begin{array}{l}4.95 \\
4.93 \\
5.00 \\
4.09\end{array}$ & $\begin{array}{l}3.67 \\
3.58 \\
3.57 \\
3.30\end{array}$ & $\begin{array}{l}33 \\
33 \\
32 \\
33\end{array}$ \\
\hline $\begin{array}{r}\mathrm{K} \text { D89-1 } \\
2 \\
3 \\
4\end{array}$ & $\begin{array}{l}4.88 \\
4.82 \\
4.83 \\
4.09\end{array}$ & $\begin{array}{l}3.80 \\
3.52 \\
3.66 \\
3.30\end{array}$ & $\begin{array}{l}34 \\
34 \\
\\
33\end{array}$ \\
\hline $\begin{array}{r}\mathrm{KG} 10-1 \\
2 \\
3 \\
4\end{array}$ & $\begin{array}{l}4.95 \\
4.54 \\
4.95 \\
4.04\end{array}$ & $\begin{array}{l}3.68 \\
3.63 \\
3.45 \\
3.42\end{array}$ & $\begin{array}{l}32 \\
33 \\
34 \\
38\end{array}$ \\
\hline $\begin{array}{r}\mathrm{K} G \mathrm{MS}-1 \\
2 \\
3 \\
4\end{array}$ & $\begin{array}{l}4.82 \\
4.81 \\
4.85 \\
4.04\end{array}$ & $\begin{array}{l}3.53 \\
3.47 \\
3.41 \\
3.42\end{array}$ & $\begin{array}{l}33 \\
\\
30 \\
38\end{array}$ \\
\hline $\begin{array}{r}\text { KGMS76-1 } \\
2 \\
3 \\
4\end{array}$ & $\begin{array}{l}4.09 \\
4.04 \\
4.04 \\
4.04\end{array}$ & $\begin{array}{r}3.30 \\
3.42 \\
\cdot \quad 3.42 \\
\cdot \quad 3.42\end{array}$ & $\begin{array}{l}33 \\
38 \\
38 \\
38\end{array}$ \\
\hline $\begin{array}{r}\mathrm{KT} 45-1 \\
2 \\
3\end{array}$ & $\begin{array}{l}4.15 \\
4.15 \\
4.15\end{array}$ & $\begin{array}{l}3.92 \\
3.92 \\
3.92\end{array}$ & $\begin{array}{l}31 \\
31 \\
31\end{array}$ \\
\hline
\end{tabular}

Table A 3 Summary of Test Results

\begin{tabular}{|c|c|c|c|}
\hline $\begin{array}{l}\text { Maximum } \\
\text { load, }\end{array}$ & $P_{r} / P_{u}{ }^{*}$ & $\begin{array}{l}\text { Cycles to crack } \\
\text { initiation }\end{array}$ & $\begin{array}{l}\text { Cycles to } \\
\text { failure }\end{array}$ \\
\hline & & \multicolumn{2}{|c|}{ in Kilocycle } \\
\hline $\begin{array}{l}3.0 \\
1.2 \\
1.6 \\
4.2 \\
3.3\end{array}$ & $\begin{array}{l}0.533 \\
0.211 \\
0.281 \\
0.640 \\
0.514\end{array}$ & $\begin{array}{r}50.0 \\
1960.8 \\
219.0 \\
19.0 \\
10.3\end{array}$ & $\begin{array}{r}55.8 \\
2377.1 \\
478.9 \\
24.6 \\
175.1\end{array}$ \\
\hline $\begin{array}{l}1.3 \\
2.1 \\
2.8 \\
5.2\end{array}$ & $\begin{array}{l}0.189 \\
0.317 \\
0.426 \\
0.665\end{array}$ & $\begin{array}{r}4290.0 \\
120.0 \\
56.0 \\
3.9\end{array}$ & $\begin{array}{r}5210.8 \\
299.4 \\
79.1 \\
11.3\end{array}$ \\
\hline $\begin{array}{l}1.8 \\
2.2 \\
3.7 \\
4.4\end{array}$ & $\begin{array}{l}0.220 \\
0.295 \\
0.471 \\
0.500\end{array}$ & $\begin{array}{r}1409.2 \\
347.0 \\
45.2 \\
28.6\end{array}$ & $\begin{array}{r}1915.8 \\
923.8 \\
128.0 \\
52.5\end{array}$ \\
\hline $\begin{array}{l}3.2 \\
1.7 \\
2.4 \\
5.8\end{array}$ & $\begin{array}{l}0.420 \\
0.227 \\
0.336 \\
0.734\end{array}$ & $\begin{array}{r}71.3 \\
6980.0 \\
280.0 \\
3.0\end{array}$ & $\begin{array}{r}107.0 \\
7322.2 \\
496.0 \\
5.8\end{array}$ \\
\hline $\begin{array}{l}4.8 \\
4.8 \\
3.0 \\
5.7\end{array}$ & $\begin{array}{l}0.580 \\
0.590 \\
0.370 \\
0.636\end{array}$ & $\begin{array}{r}100.0 \\
173.6 \\
1519.0 \\
9.5\end{array}$ & $\begin{array}{r}129.8 \\
177.7 \\
2956.2 \\
16.1\end{array}$ \\
\hline $\begin{array}{l}7.2 \\
5.4 \\
3.9 \\
3.5\end{array}$ & $\begin{array}{l}0.670 \\
0.508 \\
0.370 \\
0.331\end{array}$ & $\begin{array}{r}14.5 \\
78.0 \\
505.0 \\
1156.0\end{array}$ & $\begin{array}{r}23.9 \\
137.9 \\
1043.0 \\
5057.5\end{array}$ \\
\hline $\begin{array}{l}2.8 \\
1.5 \\
1.9\end{array}$ & $\begin{array}{l}0.381 \\
0.203 \\
0.258\end{array}$ & $\begin{array}{r}97.0 \\
550.6 \\
796.0\end{array}$ & $\begin{array}{r}132.5 \\
970.0 \\
1119.1\end{array}$ \\
\hline
\end{tabular}

* Note Eq. 2.

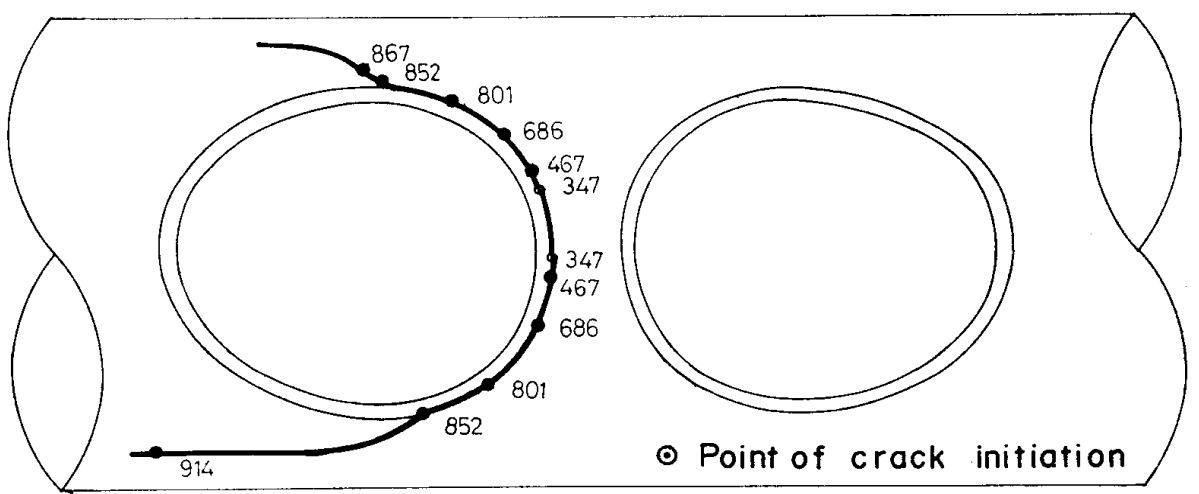

Fig. A 3 Location of Fatigue Cracks of Typical Specimen with Extended Braces (Numerals in the figure indicate number of applied cycles in kilo cycles.)

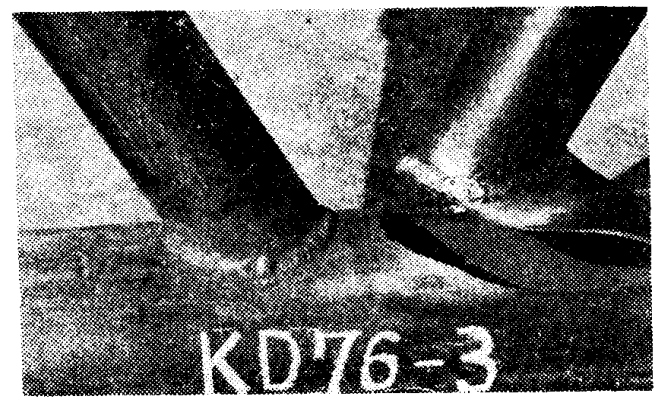

Fig. A 4 Failure Mode of Specimen with Extended Braces 


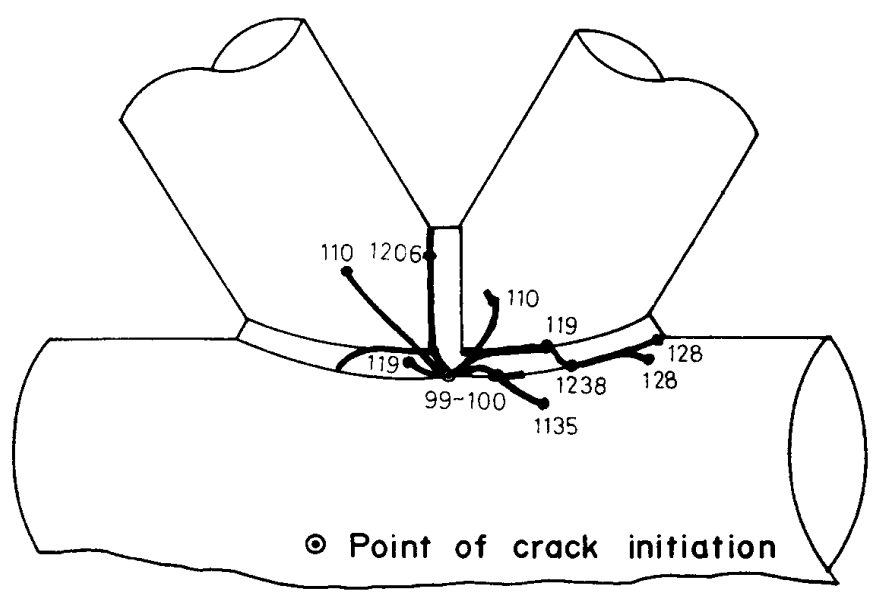

Fig. A 5 Location of Fatigue Cracks of Typical Specimens with Overlapping Braces (Numerals in the figure indicate number of applied cycles in kilo cycles.)

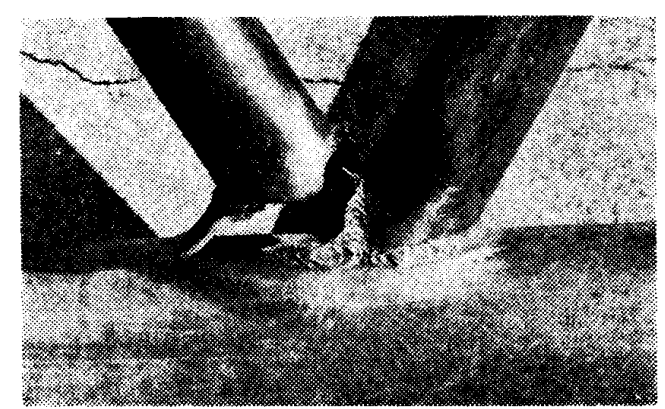

Fig. A 6 Failure Mode of Specimen with Overlapping Braces

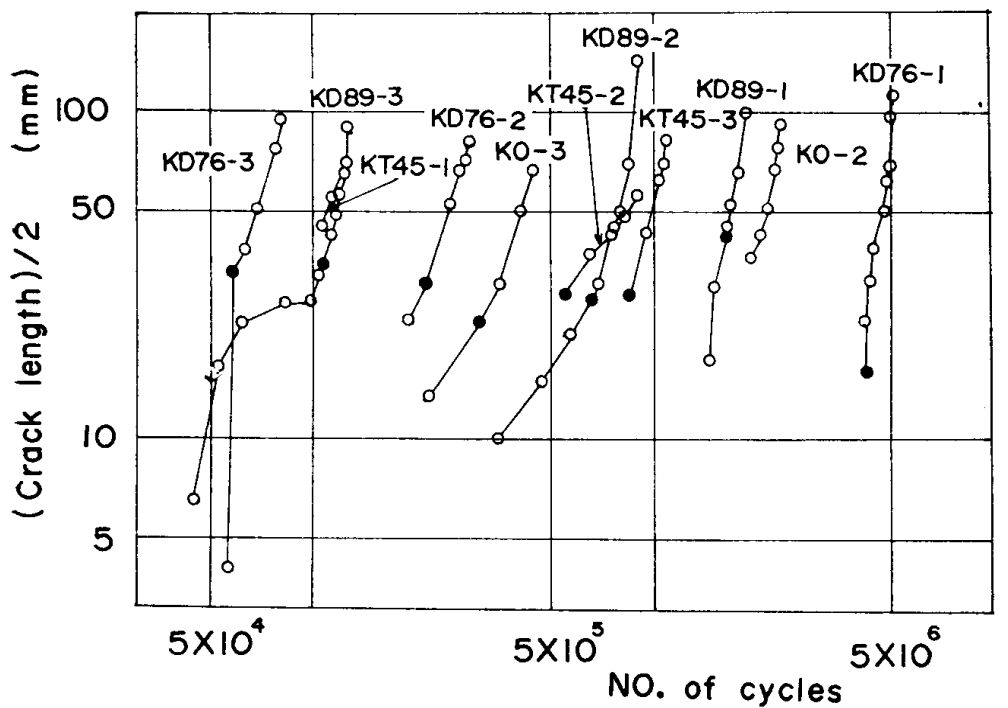

Fig. A[7 Crack Length to Cycle Relationships (Mark-indicates that the cracks penetrated through the chord wall.) 


\section{鋼管 $\mathbf{K}$ 形継手の疲労におけるいくつかの簡単な $\boldsymbol{S}-\boldsymbol{N}$ 関係 (梗概)}

$\begin{array}{ccccc}\text { 正会員 } & \text { 黑 } & \text { 羽 } & \text { 啓 } & \text { 明* } \\ \text { 同 } & \text { 許 } & \text { 斐 } & \text { 光 } & \text { 生** }\end{array}$

\section{疲労強さ}

鋼管 $\mathrm{K}$ 形継手（1 本の主管に 2 本の支管が溶接接合さ れたトラス節点）の疲労性状は，継手の形が複雑なため に，まだ不明な点が多い。

$\mathrm{K}$ 継手の弹性応力解析によると, 主管と支管の溶接継 目の趾端上に，曲げ応力による 鋭い応力集中がみられ る。変動荷重をうけるK継手では, これらの応力集中点 に疲労きれつが発生し，このきれつが十分な長さに生長 すると延性破壊する。きれつの発生・生長の過程での忘 力集中点のひずみ挙動は複雑であるので, K継手の疲労 寿命を解析的に推定することは，現在では困難である。

しかしながら，疲労試験結果を検討してみると，疲労 寿命（または疲労強さ）は静的耐力の大きい継手ほど大 きくなるようである。いま，荷重幅（荷重の全振幅） $P_{r}$ を静的耐力 $P_{u}$ で割ったものを疲労強さ $S$ とおいて, $\log S-\log N$ 座標上に実験結果を示すと, $\mathrm{K}$ 継手の $S$ $N$ 関倸泣 1 本の直線で表わせるようである（Fig. 1 お よび Fig. 2)。

ここに, 静的耐力 $P_{u}$ とは, 圧縮支管の溶接部で主管 が局部変形して継手が破壊するときの耐力である。 $P_{u}$ は管壁の曲げ剛性を表わす一つの常数として用いるの で, 疲労きれつが発生する位置が, 片振り引張力をうけ る支管の溶接部である場合でも，この支管が圧縮力をう けるときの局部変形耐力を $P_{u}$ とする。

支管どうしが溶接部で相貫しないK継手では，このよ うな局部変形耐力は実験式（1）で予測できる。しかし， 支管どうしが相貴するK継手の静的耐力を推定すること は困難であるので, 溶接継目位置での支管どうしの間隔 $g$ がゼロとして $P_{u}$ を計算することにした。

\section{鋼管 $\mathbf{K}$ 形継手の $\boldsymbol{S}-\boldsymbol{N}$ 関係}

$\mathrm{K}$ 継手の疲労强さは, 無次元量 $P_{r} / P_{u}$ で表わすと, 継手の形が変化しても1本の $S-N$ 曲線に集まり, その 曲線は，式 (3)，(4) で与えることができる。ただし， 支管どうしが相貫する継手は例外で，これらの継手の疲 労強さは，支管どうしが相貫しない継手より大きくな る。

\footnotetext{
* 熊本大学教授 工博

** 日本鋼管株式会社 工修

(昭和 48 年 3 月 5 日本稿受理 ・討論期限昭和 48 年 12 月末日)
}

このような $S-N$ 関係は, 静的耐力が増加すれば, 応 力集中が軽減され，その結果疲労強さが増加することを 示しているので，第 1 近似として妥当なものと言える。 すなわち，鋼管 $\mathrm{K}$ 継手の応力集中点の最大応力と継手の 寸法・形を決める变数との関係は, 近似的に式 (6) で表 わせる。式 (6) から，応力集中点で降伏が始まるときに 継手に作用する荷重 $P_{y}$ は式 (8) となる。式 (8) は式 （1）と似た形となり，継手の寸法・形を決める変数，T (主管管厚)， $D$ (主管径)， $d$ (支管径)， $\theta$ (主管と支管 の交角）を変化させると， $P_{u}, P_{y}$ 注同じょうに増減す る。したがって, $P_{r} / P_{u}$ の形で表わした疲労強さは, $T$, $D, d, \theta$ の変化に余り影響されなくなる。鋼管 $\mathrm{K}$ 継手 では， $T, d$ が増加し， $g$ が減少すれば，管壁の局部曲 げ変形に対する剛性が大きくなり，その結果，静的およ び疲労の両方の荷重に対する抵抗力が増加するものと考 えられる。

以上の結論は著者等の行った疲労試験結果に基ずいた ものであり，継手の寸法・形は限られた範围内で変化し ているにすぎない。K継手の疲労強さに重要な影響を及 ぼすと考えられる要因について，著者等の実験の範囲を 示すと次の通りである。

1. 主管径は $139.8 \mathrm{~mm}$ および $101.6 \mathrm{~mm}$ で, 全部小 径管の供試体を用いた。

2. $D / T$ 比は 32 から 41 の間である。

3. 主管と支管の交角はすべて $60^{\circ}$ である。

継手の寸法・形がこの範囲を越えた場合にも，上と同 様な結論が導びけるか否かについて調べるために, 我国 および米国で行われたK継手の疲労試験結果について検 討してみる。後者の実験の範团は Table 1 に示してあ り,そのらち,

1. 主管径は $165.2 \mathrm{~mm}$ から $457.2 \mathrm{~mm}$ の間で変化し ている。

2. $D / T$ 比は 32 から 101 の間で変化している。

3. 主管と支管と交角は $35^{\circ}$ から $90^{\circ}$ の問で変化してい る。

前と同様に疲労強さを無次元の形 $P_{r} / P_{u}$ で表わして $S-N$ 関保を図示すると Fig. 3 の通りになる。この図 から，実験点のばらつきは大きくなるが，K継手の疲労 強さは大略 1 本の $S-N$ 曲線で代表できることが分る。 
なお，この図では，支管どうしが相貫しない継手の実験 結果のみを示している。

さらに，東ドイツの示方書から鋼管 $\mathrm{K}$ 継手の設計用疲 労強さを求めて, 本実験で得られた $S-N$ 関倸と比較す ると Fig 4 の通りになる。東ドイッの示方書は少数の 実験結果に基ずいているので, この示方書の基礎実験に 用いられたものと同じ形の継手について, 疲労強さを比 較したものである。この図からも, 本実験の $S-N$ 曲線 が妥当なものと言える。

\section{鋼管 $\mathbf{T}$ 形および十字形継手の $\boldsymbol{S}-\boldsymbol{N}$ 関係}

$\mathrm{K}$ 継手について行ったものと同様な検討を， $\mathrm{T}$ 形継 手, 十字形継手についても試みてみる。それぞれの継手 の静的耐力は，式 (11)，(12) で推定することができる。 な抢, ここでも, 静的耐力とは, 支管が圧縮力をうける ときの主管の局部変形耐斿でるとする。

$\mathrm{T}$ 継手の $S-N$ 関係を図示すると Fig. 5 の通りにな る。この実験では, 主管径が $57 \mathrm{~mm}$, 主管厚が $1.2 \mathrm{~mm}$ の小型模型供試体を用いたものと, 主管径が $165.2 \mathrm{~mm}$ から $457.2 \mathrm{~mm}$ まで変化したより大型の供試体を用い たものとの 2 種類がある。小型模型供試体の実験結果 は, 寸法効果と溶接条件の相違により, 疲学強さが大き くなるので，これらの 2 種類の実験を別の実䥐として $S-N$ 関係を調べてみる。なお， $\mathrm{T}$ 継手の奏験の範用は, $D / T$ 比が 27 から 101 まで, $d / D$ 比が 0.22 から 0.89 までである。

Fig. 5 から， T 継手の疲労強さは， $D / T$ 比抒よび $d / D$ 比の変化にかかわらず 1 本の $S-N$ 曲線（式 (13), (14)）で近似できることが分る。T 継手の $S-N$ 曲線の 勾配は，K継手の勾配に近いことに注目すべきである。

十字継手の $S-N$ 関保を Fig. 6 亿図示する。この実 験では, $D$ が $76.3 \mathrm{~mm}$ から $318.5 \mathrm{~mm}$ まで, $D / T$ 比 が 18 から 71 まで, $d / D$ 比が 0.52 から 1 まで変化し ている。

十字継手の場合でも，1本の $S-N$ 曲線によって, 全 部の供試体の疲労強さを近似的に婊わせることが分る。 この $S-N$ 曲線は, K 継手の $S-N$ 曲線に近い值にな る。

以上の通りに，鋼管 $\mathrm{T}$ および十字継手の場合でも， $S-N$ 関係は $D / T$ 比, $d / D$ 比の変化化あまり影響され ないと言える。

\section{結論}

以上の研究から導びける結論を要約すると次の通りで ある。
1. 疲労強さを静的耐力 (局部変形耐力) との比とし て表わすと，鋼管 K形継手（支管どうしが相貫しない場 合）の $S-N$ 曲線は, 継手の形状・寸法の如何にかかわ らず1本の直線で代表することができる。なおう，この結 論はかぎられた実験結果に基ずいているので，その実験 の範囲に注意する必要がある。

上でのべた $S-N$ 関係は, 簡単でしかも忘用範用が広 いので，鋼管 $\mathrm{K}$ 形継手の疲労設計に利用するここができ ると思われる。

3. 支管どうしが相貫した $\mathrm{K}$ 継手は, 静的おょび動的 な荷重に対する耐力が大きいので, 実際設計に用いれば 有利である。な就，この継手の耐力の評価方法について は, 今後の研究にまつ点が多い。

4. 鋼管 $\mathrm{T}$ 抢よび十字継手でも, $\mathrm{K}$ 継手と同椂に, 疲 学強さを静的耐力との比として表わすと, 継手の $S-N$ 曲線は $D / T$ 比, $d / D$ 比の変化にあまり影響されなくな る。

5. 統計的方法による信頼性の判定をするには, 実験 の数が十分多くないので，ここで提案する $S-N$ 関係を 実際設計に利用する際には, 設計诸の工学的判䉼が,必要 である。

\section{们 実験概要}

Fig. A 1 および Table A 1 に示すような鋼管 K 形 継手 28 個について疲学試験を行った。戴荷方法として は，2 本の支管の端部および主管の一方の端部に完全雨 振り荷重を加えた。載荷速度は $180 \mathrm{cpm}$ から $1500 \mathrm{cpm}$ の間で，供試体の寿命の長い場合には載荷速度を早め た。

疲労きれつは，溶按趾端部に生じ発見が困難であるの で, 試験中, 揮発性の浸透液を吹付けて, きれつの開閉 による泡を生じさせて発見の一助とした。きれつの発生 位㯰, 終局破壊に至るまでの伝ぱんの状態を Fig. A 3 〜 Fig. A 6 に示す。

\section{実験結果のまとめを Table A 3 亿示す。}

支管どうしが相貫しない継手では, 疲労きれつは, 両 支管の溶接継目が最も近くなる位置の溶接趾湍に発生 し, 趾端にそって生長し,さらに，主管管壁内にまでき れつが生层すると，延性破壊により継手全体が破壊し た。支管どらしが相貫する継手では, 疲学きれつは, 3 本の溶接継目が会する点付近に発生し, Fig. A 5 に示 すよらな複難な径路で伝ぱんし, 最後に支管が切断して 破壊した。

各サイクル毎のきれつの長さを Fig. A 7 亿示す。 